JIPPF, Vol. 1, Edisi 1, Halaman: 29-38

\title{
REMEDIASI KESALAHAN MENYELESAIKAN SOAL USAHA ENERGI \\ MENGGUNAKAN STRATEGI SYSTEMATIC APPROACH \\ TO PROBLEM SOLVING DI SMA \\ ${ }^{1 *}$ Wulandari, ${ }^{2}$ Stepanus, S. S, ${ }^{3}$ Syukran, M
}

1,2,3 Prodi Pendidikan Fisika, Universitas Tanjungpura, Kota Pontianak,Indonesia

*Email Korespondensi: dariw095@gmail.com

INFO ARTIKEL

Diterima 00 Juni 2020

Dipublikasikan 00 Agustus 2020

\begin{abstract}
The aim of this research is to find out the effectiveness of using Systematic Approach Strategy on remedy to reduce the total incorrect results on answering the test on the topic of work and energy on the students at SMA Negeri 1 Batu Ampar. The population in this research are 72 students. Technique of data collection in this research is intact group with 36 students as the sample. The research implements experiment method. The research use limited topic on the test consist of work and energy. Statistic test used in this research is Wilcoxon with value $\mathbf{Z}_{\text {hitung }}=$ -0.1631 , if this results are compared with value $Z_{\text {table }}$ on taraf nyata $(\alpha)=0.025$, it resulted $\mathrm{Z}_{\text {hitung }}<\mathrm{Z}_{\text {table, }}$ with the value $0.1631<1,96$. After analyze found that there are no significant differences on the total incorrect results on answering the test on the topic of work and energy by students at XI MIPA SMA Negeri 1 Batu Ampar before and after remedy. The Conclusion from the results found that the strategy can reduce the total incorrect results of the students answering the test on the topic of work and energy with effectiveness low at the average $11.18 \%$.
\end{abstract}

Keywords: Strategy, Systematic Approach to Problem Solving, Students' Error, work and energy

\section{Pendahuluan}

Pendidikan merupakan usaha sadar dan terencana untuk mewujudkan suasana belajar dalam proses pembelajaran agar peserta didik secara aktif mengembangkan potensi dirinya untuk memiliki kekuatan spiritual keagamaan, pengendalian diri, kecerdasan, akhlak mulia, serta keterampilan yang diperlukan dirinya, masyarakat, bangsa dan negara ( UU RI Nomor 20 Tahun 2003 Tentang Sistem Pendidikan Nasional).

Pendidikan merupakan salah satu tolak ukur berkualitasnya sumber daya manusia pada setiap bangsa. Agar dapat menciptakan manusia yang berkualitas tentunya pendidikan di setiap negara harus meningkat seiring perkembangan zaman. Salah satu tolak ukur kemajuan pendidikan adalah kemampuan peserta didik dalam menyelesaikan soal-soal untuk melatih tingkat berpikir peserta didik yang diberikan baik itu mata pelajaran bidang sosial maupun bidang sains. Salah satu mata pelajaran yang melatih tingkat berpikir peserta didik adalah pelajaran Fisika. Teori yang dikemukakan Gagne (dalam Priadi, 2017) bahwa ketermpilan intelektual tingkat tinggi dapat dikembangkan melalui pemecahan masalah. Kemampuan pemecahan masalah peserta didik dapat dilihat dari hasil Programme for International Student Assesment (PISA).

Pada proses pembelajaran yang dilakukan, ada hambatan yang dialami oleh guru dan peserta didik. Salah satu diantaranya adalah kendala yang dihadapi oleh para peserta didik, yaitu mereka cendrung sulit untuk memecahkan masalah khususnya pada pelajaran fisika. Kesulitan peserta didik dalam memecahkan masalah fisika karena kurangnya pemahaman dan keterampilan. Mata pelajaran fisika selalu menyuguhkan masalah yang menuntut peserta didik berpikir kritis dan sistematis untuk menyelesaikannya (Ogunleye, 2009).

Menurut Gunel, Hand, dan Gunduz (dalam Abdurrahman dkk, 2011) Fisika sebagai sebuah mata pelajaran, dalam menguasainya dibutuhkan pemahaman dan kemampuan cara representasi yang berbeda-beda atau multirepresentasi untuk konsep yang sedang dipelajari. Namun, ketidakmampuan peserta didik menggunakan multi representasi dalam memahami konsep fisika nampaknya telah menjadi halangan/batas pemahaman mereka. 
Hasil observasi di sekolah SMA Negeri 1 Batu Ampar bahwa guru yang mengampu pelajaran fisika menyatakan bukan berlatar belakang dari pendidikan fisika sehingga terdapat beberapa kendala dalam penyampaian materi belum lagi kurangnya minat peserta didik untuk menguasi pelajaran tersebut hal ini diperkuat ketika peserta didik diberikan beberapa soal sederhana sebagian besar peserta didik menjawab soal dengan hasil akhir tanpa menggunakan cara penyelesaian soal yang benar.

Dengan kata lain, kemampuan Penguasaan konsep fisika sangat berkaitan dengan bagaimana menggunakan berbagai bahasa sains dalam pembelajaran fisika, seperti kata (oral dan menulis), visual (gambar, grafik, simulasi), simbol dan persamaan, gerak-gerik tubuh, bermain peran, presentasi, dan lain-lain yang akan memungkinkan peserta didik mempelajari fisika melalui pengembangan kemampuan mental berpikir dengan baik. Inilah yang dinamakan pendekatan multi representasi atau multimode representasi Waldrip ( dalam Abdurrahman, 2011).

Seluruh fenomena fisika dapat dijelaskan melalui sejumlah hukum alam dasar. Akan tetapi untuk memprediksi atau menentukan suatu nilai dalam proses fisika diperlukan adanya pengetahuan tentang penalaran (teoritis) secara terstruktur, agar dapat dirumuskan dan diolah. Perumusan secara kuantitatif dalam dalam model mamematika sangat penting dalam hal ini. Melalui rumusan matimatis, memungkinkan para peserta didik mempunyai jangkauan analisis yang mendalam terhadap persoalan yang dikaji, dan memberi kemampuan prediktif (meramal), sebagai hasil kuantitatif, terhadap kemungkinan yang akan terjadi.

Berdasarkan penelitian yang dilakukan oleh Hastuti (2012) ditemukan beberapa penyebab kesalahan peserta didik kelas X SMA Negeri 1 Karanganyar dalam menyelesaikan soal fisika tentang materi kalor. Pertama, penyebab kesalahan konsep adalah peserta didik tidak memahami materi yang disampaikan oleh guru, peserta didik tidak mempelajari kembali materi yang tidak dipahaminya, peserta didik tidak berani bertanya kepada guru apabila belum memahami materi, dan kurang berlatih mengerjakan soal yang bevariasi. Kedua, penyebab kesalahan menggunakan data adalah peserta didik kurang teliti dalam membaca soal dan tidak mengetahui lambang besaran fisika. Ketiga, penyebab kesalahan strategi adalah peserta didik tidak paham apa yang ditanyakan oleh soal. Keempat, penyebab kesalahan hitung adalah kurangnya pemahaman peserta didik dalam menghitung dan kurang ketelitian. Kelima, penyebab soal tidak direspon oleh peserta didik adalah peserta didik tidak memahami materi, peserta didik tidak paham yang diketahui dari soal dan kurang kesiapan.

Hasil penelitian serupa ditemukan juga oleh Sari (2013) bahwa beberapa penyebab kesalahan peserta didik menyelesaikan soal fisika antara lain: peserta didik lupa, tidak memahami lambang besaran fisika dari data-data yang disebutkan pada soal, salah mengartikan maksud soal, kurang teliti dalam membaca serta memahami maksud soal, kurang belajar, kurang memperhatikan penjelasan guru, tidak berani mengajukan pertanyaan ketika ada materi yang belum dipahami, kurang teliti, kurang latihan soal dan variasi dalam latihan soal, terburu-buru, dan kekurangan waktu.

Systematic approach to problem solving adalah strategi pemecahan masalah yang dilakukan secara sistematis, karena strategi ini dapat membimbing peserta didik dalam menyelesaikan masalah khususnya latihan soal. Menurut Wena (2009) SAPS terdiri dari empat tahapan: 1) analisis soal, yaitu, peserta didik membaca seluruh soal, menulis besran yang ditanyakan, dan memperkirakan jawaban. 2) Transformasi soal, yaitu peserta didik mengecek apakah soal sudah berbentuk standar, menulis rumus/ hubungan antar besaran, dan mengecek apakah hubungan yang ditulis relevan dengan soal. 3) Operasi perhitungan, yaitu peserta didik mensubtitusikan data yang diketahui ke dalam bentuk standar yang telah diperoleh, kemudian melakukan perhitungan. dan 4) Pengecekan serta interpretasi hasil, yaitu mengecek jawaban dengan cara membandingkan dengan perkiraan jawaban yang dibuat.

Saputra (2013) dalam penelitiannya menunjukkan bahwa penggunaan strategi pemecahan masalah sistematis systematic approach to problem solving terhadap pencapaian hasil belajar ranah kognitif dapat meningkatkan jumlah peserta didik yang mencapai ketuntasan yang semula hanya 32,35\% naik menjadi 97,05\%. Sejalan dengan penelitian tersebut, Ansar (2009) menemukan penggunaan SAPS mampu meningkatkan ketuntasan belajar peserta didik yang semula 43,9\% naik menjadi 85,4\%. Fauzi (2016) dalam penelitiannya menemukan bahwa SAPS 
dapat menurunkan kesalahan peserta didik dalam menyelesaikan soal uaraian rata-rata harga proporsi penurunan presentase jumlah peserta didik yang salah sebesar 59,83\% atau 0,5983.

\section{Metode Penelitian}

Bentuk penelitian yang sesuai dengan penelitian ini adalah pre-eksperimental design dengan rancangan one group pre-test post-test. Bentuk design ini dipilih karena menggunakan satu kelompok subjek (Sugiono,2017). Populasi dalam penelitian ini adalah seluruh peserta didik kelas XI IPA yaitu kelas XI IPA 1 dan XI IPA 2 dengan total peserta didik yaitu 72 orang di SMA Negeri 1 Batu Ampar tahun ajaran 2018/2019 dengan ketentuan telah mengikuti mata pelajaran fisika pada materi usaha dan energi.

Teknik pengambilan sampel pada penelitian ini dilakukan dengan cara intact group (kelompok utuh). Menurut Leo Sutrisno (dalam Fauzi, 2016) disebutkan bahwa pengambilan sampel dengan cara intact group merupakan pengambilan sampel secara utuh dari populasi yang memiliki sifat dan karaktersitik homogen dengan menetapkan satu atau beberapa kelas sebagai kelompok yang akan diteliti. Selanjutnya satu kelas utuh dipilih secara acak melalui cabut undi dan terpilihlah kelas X IPA 2 yang terdiri dari 34 peserta didik yang dijadikan sampel pada penelitian ini.

Alat pengumpul data pada penelitian ini adalah berupa pre-test dan post-test berbentuk essay (uraian) terbatas sebanyak 7 soal. Tes yang diberikan dalam penelitian ini adalah materi usaha dan energi. validitas tes uraian terbatas yang digunakan adalah validitas isi, yaitu untuk membandingkan antara instrumen dengan materi pelajaran yang telah diajarkan. Validasi tes dilakukan oleh validator pakar/ahli yang sudah pengalaman menekuni pembelajaran fisika yaitu dua orang dosen Pendidikan Fisika FKIP Untan dan satu oramg guru fisika SMA. Dari hasil perhitungan rata-rata oleh ketiga validator tersebut sebesar 4,22 yang terkategori tinggi dan layak digunakan. Pengujian reliabilitas instrumen dengan menggunakan internal consistency Yaitu dilakukan dengan cara mencobakan instrument sekali saja SMA Negeri 1 Batu Ampar dengan koefisien nilai reabelitas tes yang digunakan pada penelitian ini terkategori sedang yaitu 0,53.

\section{Tahap Persiapan}

Berikut langkah-langkah yang dilakukan pada tahap persiapan yaitu: (1) Melakukan prariset ke SMA Negeri 1 Batu Ampar; (2) Menyusun desain penelitian; (3) Membuat perangkat pembelajaran dan instrument penelitian; (4) Melakukan validasi perangkat pembelajaran; (5) Melakukan uji coba soal tes di kelas X IPA SMA Negeri 1 Batu Ampar; (6) Menganalisis data hasil uji coba soal tes; (7) Merevisi soal tes setelah mengetahui hasil dari uji coba soal.

\section{Tahap Pelaksanaan}

Langkah-langkah yang dilakukan pada tahap pelaksanaan yaitu: (1) Memberikan soal tes awal (pre-test); (2) Memberi skor pre-test dengan tujuan untuk mengetahui skor awal peserta didik dan jumlah peserta didik yang tidak dapat menyelesaikan soal sebelum diberikan remediasi; (3) Memberikan treatment, yaitu remediasi dengan menggunakan strategi systematic approach to problem solving pada peserta didik kelas XI MIPA SMA Negeri 1 Batu Ampar; (4) Memberikan soal tes akhir (post-test); (5) Memberi skor post-test.

\section{Tahap Akhir}

Langkah-langkah yang dilakukan pada tahap akhir yaitu: (1) Menganalisis data; (2) Menganalisis hasil pre-test dan post-test; (3) Mendeskripsikan hasil pengolahan data dan menyimpulkan sebagai jawaban dari masalah dalam penelitian ini; (4) Menyusun laporan penelitian.

\section{Hasil dan Pembahasan}

\subsection{Hasil}

Dilakukan penelitian di SMA Negeri 1 Batu Ampar pada tanggal 19 Juli hingga 26 juli 2019 dengan jumlah pertemuan sebanyak empat kali yaitu satu kali pre-test, dua kali pelaksanaan pembelajaran remidiasi strategi 
systematic approach to problem solving dan satu kali post-test. Adapun peserta didik yang dijadikan sampel pada penelitian ini adalah kelas XI MIPA 2 yang berjumlah 36 orang namun, karena dua diantaranya berhalangan hadir sehingga jumlah peserta didik yang ikut serta pada penelitian ini hanya berjumlah 34 orang.

\section{Profil Kesalahan Peserta Didik Menyelesaikan Soal Usaha dan Energi}

Profil kesalahan peserta didik di kelas XI MIPA 2 dalam menyelesaikan soal usaha energi dijelaskan dalam bentuk Tabel 1 dan 2 di bawah ini diperoleh dari hasil pre-tes dan posttest.

Tabel 1. Jenis Kesalahan Pre-test

\begin{tabular}{|c|c|c|c|c|}
\hline \multirow[b]{2}{*}{ No } & \multicolumn{4}{|c|}{ Jenis kesalahan pretest } \\
\hline & $\begin{array}{c}\text { Membuat skema } \\
\text { soal }\end{array}$ & $\begin{array}{l}\text { Menuliskan data yang } \\
\text { diketahui dan ditanyakan }\end{array}$ & $\begin{array}{c}\text { Tranformasi soal ke } \\
\text { bentuk standar }\end{array}$ & Operasi Hitung \\
\hline 1 & \multirow{6}{*}{$\begin{array}{c}\text { Tidak membuat } \\
\text { skema soal }\end{array}$} & \multirow{6}{*}{$\begin{array}{l}\text { - Tidak menuliskan apa yang } \\
\text { diketahui dan ditanyakan } \\
\text { pada soal } \\
\text { - Salah dalam menuliskan } \\
\text { lambang dan satuan yang } \\
\text { diketahui dan ditanyakan } \\
\text { pada soal }\end{array}$} & \multirow{6}{*}{ 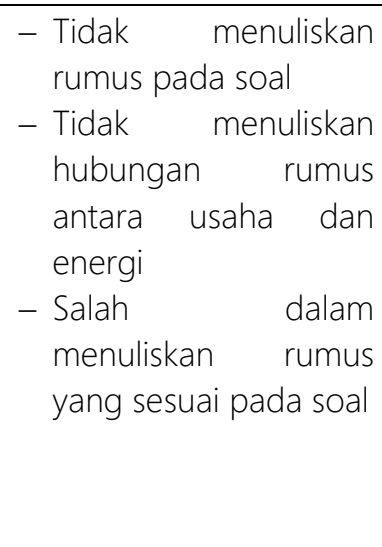 } & \multirow{6}{*}{$\begin{array}{l}\text { - Tidak melakukan } \\
\text { perhitungan } \\
\text { - Salah melakukan } \\
\text { perhitungan } \\
\text { - Salah dalam } \\
\text { memasukan satuan } \\
\text { yang sesuai pada } \\
\text { rumus. }\end{array}$} \\
\hline 2 & & & & \\
\hline 3 & & & & \\
\hline 4 & & & & \\
\hline 5 & & & & \\
\hline 6 & & & & \\
\hline & $100 \%$ & $83,33 \%$ & $99,92 \%$ & $100 \%$ \\
\hline
\end{tabular}

Tabel 2. Jenis Kesalahan Post-test

\begin{tabular}{|c|c|c|c|c|}
\hline \multirow[b]{2}{*}{ No } & \multicolumn{4}{|c|}{ Jenis kesalahan posttest } \\
\hline & Membuat skema soal & $\begin{array}{c}\text { Menuliskan data } \\
\text { yang diketahui dan } \\
\text { ditanyakan }\end{array}$ & $\begin{array}{c}\text { Tranformasi soal ke } \\
\text { bentuk standar }\end{array}$ & Operasi Hitung \\
\hline 1 & 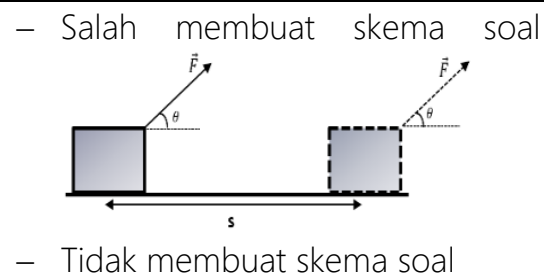 & $\begin{array}{l}\text { - Tidak menuliskan } \\
\text { apa yang } \\
\text { diketahui dan } \\
\text { ditanyakan pada } \\
\text { soal }\end{array}$ & $\begin{array}{r}\text { - Tidak menuliskan } \\
\text { rumus pada soal } \\
\text { - Tidak menuliskan } \\
\text { hubungan rumus } \\
\text { antara usaha dan }\end{array}$ & $\begin{array}{l}\text { - Tidak } \\
\text { melakukan } \\
\text { perhitungan } \\
\text { - Salah } \\
\text { melakukan }\end{array}$ \\
\hline 2 & - Salah membuat skema soal & $\begin{array}{l}\text { - Salah dalam } \\
\text { menuliskan } \\
\text { lambang dan } \\
\text { satuan yang } \\
\text { diketahui dan } \\
\text { ditanyakan pada } \\
\text { soal }\end{array}$ & $\begin{array}{l}\text { energi } \\
\text { - Salah dalam } \\
\text { menuliskan } \\
\text { rumus yang } \\
\text { sesuai pada soal }\end{array}$ & $\begin{array}{l}\text { perhitungan } \\
\text { - Salah dalam } \\
\text { memasukan } \\
\text { satuan yang }\end{array}$ \\
\hline
\end{tabular}




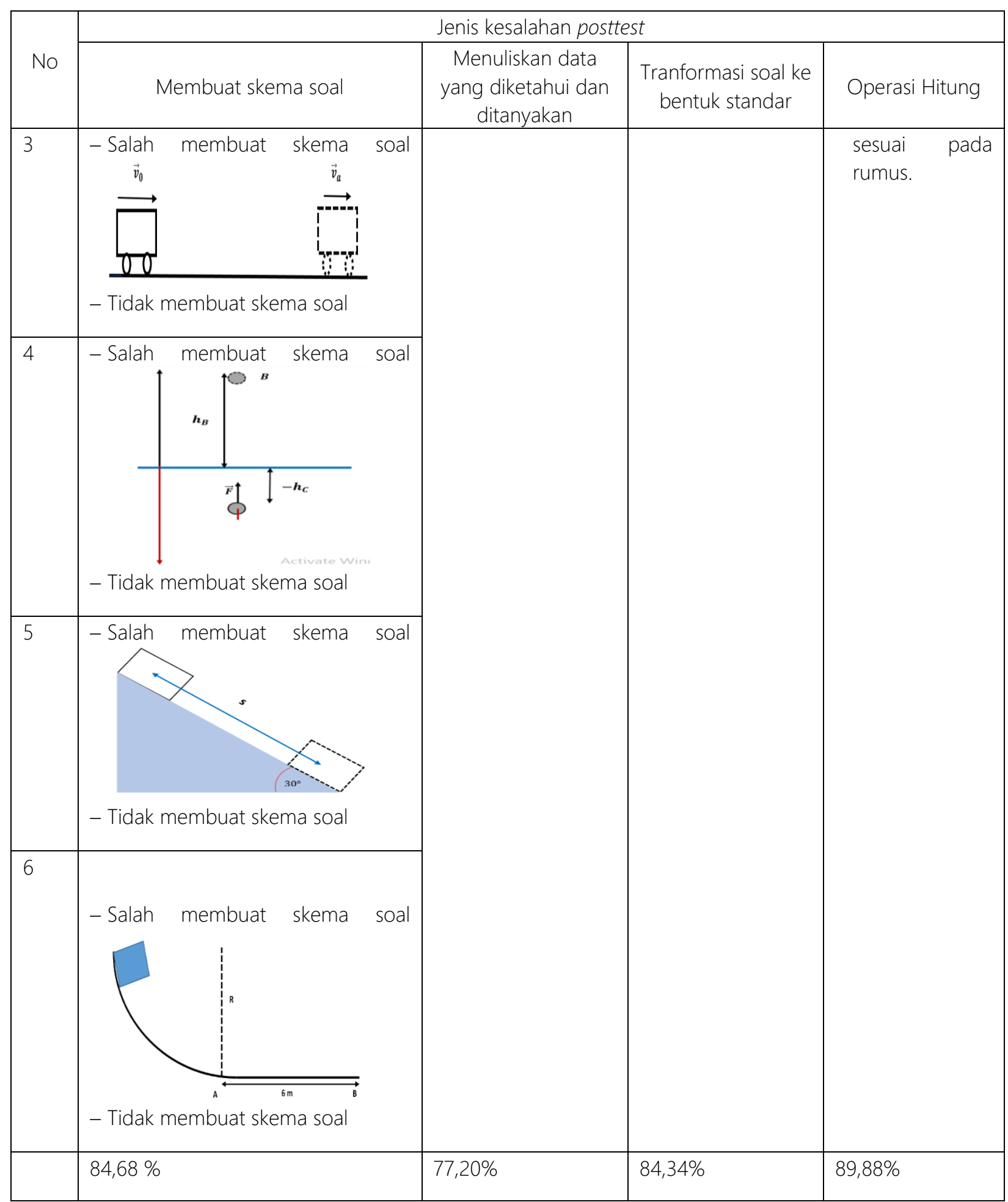

Perbedaan Jumlah Kesalahan Peserta Didik Menyelesaikan Soal Sebelum dan Sesudah Diremediasi Menggunakan Strategi Systematic Approach to Problem Solving.

Berdasarkan perhitungan yang dilakukan dengan menggunakan rumus $Z$ diperoleh nilai $Z_{\text {hitung }}$ sebesar $=-$ 0.1631 diamana harga (-) tidak diperhitungkan karena harga mutlak. Hasil ini apabila dibandingkan dengan nilai $Z_{\text {tabel }}$ dengan taraf nyata $(\alpha)=0,025$ ternyata $Z_{\text {hitung }}<Z_{\text {tabel, }}$ yaitu $0.17391<1,96$. Dari hasil tersebut dapat diketahui bahwa tidak terdapat perbedaan yang signifikan pada jumlah kesalahan menyelesaikan soal uraian usaha dan energi di Kelas XI MIPA SMA Negeri 1 Batu Ampar sebelum dan sesudah diberikan remediasi. 
Pengaruh Penggunaan Strategi Systematic Approach To Problem Solving Terhadap Penurunan Jumlah Kesalahan Peserta Didik Menyelesaikan Soal

Untuk mengetahui seberapa besar pengaruh remediasi menggunakan strategi systematic approach to problem solving dapat ditentukan dengan harga effect size menurut aturan ruas jari setelah diketahui terdapat perbedaan yang pada jumlah skor kesalahan siswa menyelesaikan soal uraian tentang usaha dan energi di kelas XI MIPA SMA Negeri 1 Batu Ampar sebelum dan sesudah diremediasi. Adapun untuk menentukan efektifitas dihitung dengan rumus harga proporsi penurunan persentase $\Delta S=\frac{s_{a}-s_{p}}{s_{a}} \times 100 \%$ ditunjukkan pada Tabel 3

Tabel 3. Efektifitas Penurunan Jumlah Kesalahan Peserta Didik Menyelesaikan Soal

\begin{tabular}{|c|c|c|c|c|c|c|}
\hline \multirow{3}{*}{ Sub Materi } & \multicolumn{4}{|c|}{ Skor Kesalahan Tiap Soal } & \multirow{3}{*}{$\begin{array}{c}\Delta \boldsymbol{S} \\
(\%)\end{array}$} & \multirow{3}{*}{ Efektifitas } \\
\hline & \multicolumn{2}{|c|}{ Pretest } & \multicolumn{2}{|c|}{ Posttest } & & \\
\hline & $S_{a}$ & $\%$ & $S_{p}$ & $\%$ & & \\
\hline Usaha Pada Benda Di Atas Bidang Datar & 1263 & 73,43 & 740 & 43,02 & 41,41 & Sedang \\
\hline Usaha Pada Benda Di Atas Bidang Miring & 803 & 94,47 & 611 & 71,88 & 22,59 & Rendah \\
\hline $\begin{array}{l}\text { Usaha Akibat Perubahan Energi Kinetik } \\
\text { Benda }\end{array}$ & 580 & 94,77 & 576 & 94,12 & 0,65 & Rendah \\
\hline $\begin{array}{l}\text { Usaha Akibat Perubahan Energi Potensial } \\
\text { Gravitasi }\end{array}$ & 1015 & 99,50 & 990 & 97,06 & 2,44 & Rendah \\
\hline $\begin{array}{l}\text { Usaha Pada Benda Akibat Perubahan Energi } \\
\text { Mekanik }\end{array}$ & 1456 & 99,59 & 1448 & 99,04 & 0,55 & Rendah \\
\hline Hukum Kekekalan Energi Mekanik & 907 & 98,80 & 912 & 99,35 & $-0,55$ & Negatif \\
\hline Rata-Rata Harga Proporsi Penurunan Pers & & & & & 11,18 & Rendah \\
\hline
\end{tabular}

\section{Keterangan:}

$\mathrm{Sa}=$ Jumlah skor kesalahan peserta didik dalam menyelesaikan soal pre-test

$\mathrm{Sp}=$ Jumlah skor kesalahan peserta didik dalam menyelesaikan soal post-test

$\Delta S=$ Harga proporsi penurunan jumlah skor kesalahanpeserta didik

Berdasarkan Tabel 3 dapat diketahui bahwa remediasi dengan pengajaran ulang menggunakan strategi systematic approach to problem solving secara umum dapat menurunkan jumlah kesalahan peserta didik dalam menyelesaikan soal yaitu 9,515\%. Namun untuk sub materi hukum kekekalan energi mekanik tidak terjadi penurunan kesalahan peserta didik dalam menyelesaikan soal yaitu $-0,55 \%$.

\subsection{Pembahasan}

Bentuk penelitian yang digunakan di SMA Negeri 1 Batu Ampar kelas XI MIPA 2 adalah pre-eksperimental dengan rancangan one group pretest-posttest design. Dari hasil penelitian ini diperoleh bahwa penggunaan strategi systematic approach to problem solving tidak berpengaruh terhadap meremidiasi peserta didik untuk menurunkan jumlah kesalahan menyelesaikan soal uraian tentang usaha dan energi. Hal ini disebabkan pada saat penelitian dilakukan ternyata peserta didik belum mempelajari materi yang berkaitan dengan usaha energi yaitu vektor, dan dinamika partikel sebelumnya yang seharusnya sudah dipelajari di kelas sepuluh semester genap sehingga peserta didik belum siap untuk menerima pelajaran berikutnya alasan ini diperkuat dengan penjelasan Slameto (2015) 
menyatakan bahwa salah satu yang mempengaruhi karakteristik kognitif peserta didik adalah aspek kesiapan yaitu kesiapan keterampilan, pengetahuan dan pengertian yang lain yang telah dipelajari. Menurut pendapatnya ia menyatakan bahwa peserta didik sebelum mempelajari permulaan ia belum siap untuk belajar yang berikutnya sehingga ada prasyarat dan kosyarat dalam belajar. Oleh sebab itu, pengajaran remidial yang peneliti terapkan berbeda dengan proses belajar mengajar biasa sehingga respon peserta didik tidak sesuai yang diharapkan. Alasan ini diperkuat dengan penjelasan Kunandar (2015) yang menyatakan bahwa terdapat perbedaan antara pembelajaran remidial dengan pembelajaran biasa dalam segi tujuan dimana pengajaran biasa diarahkan pada penguasaan (materi) bahan secara tuntas, sehingga tujuan instruksional maupun tujuan pengiring tercapai secara maksimal. Sedangkan pengajaran remidial lebih diarahkan pada peningkatan penguasaan bahan sehingga sekurang-kurangnya peserta didik yang bersangkutan dapat memenuhi kriteria keberhasilan minimal yang mungkin diterima.

\section{Profil Kesalahan Peserta Didik Menyelesaikan Soal Usaha dan Energi}

Pada Tabel 1 dan 2 dapat dilihat bahwa kesalahan peserta didik dalam menyelesaikan soal berdasarkan tahapan systematic approach to problem solving sebagai berikut: 1) membuat skema soal dengan presentase kesalahan ratarata pretest 100\% dan posttest $84,68 \%$. Pada tahapan ini kesalahan peserta didik dari hasi pretest secara keseluruhan tidak menggambarkan skema kasus soal sedangkan hasil posttest sebagian peserta didik sudah bisa menggambarkan skema soal namun terdapat kesalahan dalam menggambarkan skema soal seperti komponen gaya yang bekerja pada benda tidak digambarkan secara keseluruhan sesuai kasus pada soal tersebut; 2) menuliskan informasi yang diketahui serta ditanyakan pada soal dengan presentase kesalahan rata-rata pretest 83,33\% dan posttest 77,20\%. Pada tahapan ini kesalahan peserta didik secara umum ketika menyelesaikan soal pretest dan posttest sama yaitu tidak menuliskan apa yang diketahui dan ditanyakan pada soal serta salah ketika menuliskan lambang dan satuan yang diketahui dan ditanyakan pada soal tersebut; 3) transformasi soal kebentuk standar dengan presentase kesalahan rata-rata pretest 99,92\% dan posttest 84,34\%. Pada tahapan ini kesalahan peserta didik secara umum ketika menyelesaikan soal pretest dan posttest sama yaitu tidak menuliskan rumus pada soal, tidak menuliskan hubungan rumus antara usaa dan energi, salah dalam menuliskan rumus yang sesuai pada soal; 4) operasi hitung dengan presentase kesalahan rata-rata pretest 100\% dan posttest 89,87\%. Pada tahapan ini kesalahan peserta didik secara umum ketika menyelesaikan soal pretest dan posttest sama yaitu tidak melakukan perhitungan, salah melakukan perhitungan, salah dalam memasukan satuan yang sesuai pada rumus. Kesalahan pada operasi htung disebabkan peserta didik tidak mentransformasi soal ke bentuk standar dengan benar sehingga perhitungan yang dilakukan tidak sesuai dengan apa yang harus dihitung pada soal tersebut.

Perbedaan Jumlah Kesalahan Peserta Didik Menyelesaikan Soal Uraian Usaha Dan Energi Sebelum dan Sesudah Diremediasi

Berdasarkan penelitian yang telah dilakukan yaitu tentang perbedaan jumlah kesalahan peserta didik menyelesaikan soal uraian usaha dan energi sebelum dan sesudah diremediasi ditemukan tidak terjadi perbedaan yang signifikan pada jumlah kesalahan menyelesaikan soal sebelum dan sesudah diremediasi yang dapat dilihat dari hasil perhitungan uji wilcoxon dengan taraf kesalahan $(\alpha)$ sebesar 2.25\%. Hasil tersebut menunjukkan bahwa penerapan strategi systematic approach to problem solving tidak dapat mengurangi jumlah kesalahan peserta didik ketika menyelesaikan soal usaha dan energi secara signifikan. Hal ini disebabkan peserta didik yang melakukan pembelajaran ulang atau remidiasi belum pernah menerima materi usaha dan energi sebelumnya padahal materi tersebut harusnya sudah diterima peserta didik di kelas sepuluh sehingga sangat berpengaruh terhadap hasil setelah diremidiasi karena rancangan remidiasi yang tujuannya untuk melakukan pembelajaran ulang bagi peserta didik yang telah menerima materi tersebut sebelumnya. Pernyataan ini diperkuat dengan pendapat Gagne (dalam Ratna, 2011) Bahwa pada kejadian belajar terdapat fase perolehan, apabila peserta didik memperhatikan informasi yang relevan, ia telah siap menerima pelajaran. Informasi disajikan tidak langsung disimpan dalam memori. Informasi itu diubah menjadi bentuk yang bermakna yang dihubungkan dengan informasi yang telah ada dalam memori peserta 
didik. Informasi yang dimaksud pada penelitian ini adalah materi yang relevan dengan usaha dan energi yaitu vektor dan dinamika partikel.

Pengaruh Remediasi Menggunakan Strategi Systematic Approach To Problem Solving Terhadap Penurunan Jumlah Kesalahan Peserta Didik Menyelesaikan Soal

Hasil penelitian ini ditemukan bahwa terdapat penurunan jumlah kesalahan peserta didik menyelesaikan soal usaha dan energi setelah diberikan pembelajaran ulang berupa remidiasi menggunakan systematic approach to problem solving dengan presentase rata-rata tergolong rendah yaitu 9,515\%. secara umum nilai presentase tersebut dipengaruhi oleh keterbatasan peneliti dalam mengendalikan kondisi dan situasi peserta didik yang belum pernah menerima materi yang digunakan untuk penelitian yaitu usaha dan energi pada kelas sepuluh hal tersebut diketahui ketika pelaksanaan penelitian akan dilakukan berdasarkan pernyataan peserta didik itu sendiri. Selain itu, efektifitas yang rendah juga disebabkan karena peserta didik belum terbiasa dengan strategi yang diterapkan. Pernyataan ini diperkuat dengan pernyataan Gagne (dalam Ratna, 2011) bahwa fase-fase dalam satu tindakan belajar terdiri atas delapan fase salah satunya fase retensi yaitu informasi baru yang diperoleh harus dipindahkan dari memori jangka pendek ke memori jangka panjang melalui pengulangan kembali, praktik, elaborasi, atau lain-lainnya. Namun, berhubung materi usaha dan energi harusnya sudah dipelajari di kelas sepuluh penelitian tetap dilaksanakan dengan kondisi peserta didik yang belum pernah menerima pembelajaran tersebut sebelumnya.

\section{Kesimpulan}

Profil kesalahan berdasarkan tahapan systematic approach to problem solving dapat dilihat bahwa tahapan yang lebih membantu peserta didik ketika menyelesaikan soal adalah tahapan menggambarkan skema soal dan transformasi soal ke bentuk standar dengan selisih presentase penurunan kesalahan sebesar 15,32\% dan 15,58\%. Tidak terdapat perbedaan yang signifikan pada jumlah kesalahan menyelesaikan soal uraian usaha dan energi di Kelas XI MIPA SMA Negeri 1 Batu Ampar sebelum dan sesudah diberikan remediasi menggunakan strategi systematic approach to problem solving. Hasil ini diperoleh menggunakan uji wilcoxon yaitu dengan membandingkan nilai $Z_{\text {tabel }}$ dan $Z_{\text {hitung }}$ dengan taraf nyata $(\alpha)=0,025$ ternyata $Z_{\text {hitung }}<Z_{\text {tabel, }}$ yaitu $0.1631<1,96$. Terdapat penurunan jumlah kesalahan peserta didik menyelesaikan soal usaha dan energi setelah diberikan pembelajaran ulang berupa remidiasi menggunakan systematic approach to problem solving dengan presentase rata-rata tergolong rendah yaitu $11,18 \%$.

\section{Referensi}

(2003). Undang-Undang No.20 Tahun 2003 tentang Sistem Pendidikan Nasional. Jakarta: Depdiknas.

Abdurrahman \& Liliasari, dkk. 2011. Implementasi Pembelajaran Berbasis Multi Representasi untuk Meningkatkan Penguasaan Konsep Fisika Kuantum. Lampung: Universitas Lampung (Jurnal).

Ansar. 2009. Meningkatkan Hasil Belajar Siswa Kelas XII IPA 1 SMA Negeri 1 Gangking Melalui Penggunaan Sysematic Approach to Problem Solving (Studi pada Materi Pokok Sifat Koligatif Larutan). Jurnal Chemica. 10 (1): 19-27.

Fauzi, Reva. 2016. Remidiasi Kesalahan Siswa enyelesaikan Soal-Soal Usaha dan Energi menggunakan Strategi Systematic Approach to Problem Solving Berbasis Multirepresentasi di kelas XI MIA SMAN 7 Pontianak. Pontianak: FKIP UNTAN (skripsi).

Hastuti, Isnani \& Surantoro, dkk. 2012. Analisis Kesalahan dalam Menyelesaikan Soal Materi Pokok Kalor pada Siswa Kelas X SMA. Surakarta: FKIP UNS (Jurnal).

Kunandar. 2015. Penilaian Autentik (Penilaian Hasil Belajar Peserta Didik Berdasarkan Kurikulum 2013). Jakarta: Rajawali Pers

Ogunleye, A.O. 2009. Teacher and Students Perceptions of Student Problem-Solving Difficulties in Physics: Implications for Remidiation. Journal of College Teaching and Learning; 6(7): 85-90 
Priadi. 2017. Penggunaan Systematic Approach to Problem Solving Berbantuan Self-Diagnostik Sheet untuk Meningkatkan Kemampuan Menyelesaikan Soal. Pontianak: FKIP UNTAN (skripsi).

Ratna, W.D. 2011. Teori-Teori Belajar dan Pembelajaran. Jakarta: Erlangga.

Sari, DM \& Surantoro, dkk. 2013. Analisis Kesalahandalam Menyelesaikan soal Materi Termodinamika Pada Siswa SMA. Surakarta : Universitas Sebelas maret (Jurnal).

Saputra, Afriyola., Djamas, Djusmaini. \& Yulkifli. 2013. Pengaruh Strategi Pemecahan Masalah Sistematis Berbantuan Solution Path Online (SPO) Terhadap Hasil Belajar Fisika Siswa Kelas X SMAN 2 Batang Kapas. Jurnal Pendidikan Fisika. 1: 77.

Slameto. 2015. Belajar dan Faktor-Faktor yang Mempengaruhi. Jakarta: Rineka Cipta

Wena, Made. 2009. Strategi Pembelajaran Inovatif Kontemporer. Suatu Tinjauan Konseptual Operasional. Jakarta: Bumi Aksara 